\title{
Defective Phage Formation by Lysogens of Integration Deficient Phage P22 Mutants'
}

\author{
HAMILTON O. SMITH ${ }^{2}$ \\ Department of Human Genetics and the Lawrence D. Buhl Research Center for Human Genetics, \\ University of Michigan, Ann Arbor, Michigan \\ Accepted September 28,1967
}

\begin{abstract}
Integration deficient $(L)$ mutants of phage P22 can be complemented with $L^{+}$ phage to yield $L$ mutant lysogens. Once established the $L$ prophage is stable in the absence of $L^{+}$function. Ultraviolet or thermal induction of $L$ lysogens leads to production of defective phage particles and low yields of infectious phage. The defective particles contain a normal amount of DNA but the DNA is mainly bacterial in origin and appears to derive from the pro $C$ region adjacent to one end of the prophage. The defective lysates transduce pro $C$ at high frequency relative to other bacterial markers. The representation of phage genes is strongly polar with markers distal to pro $C$ being rarely present. It appears that $L^{+}$function is required not only for efficient integration of the prophage, but for normal recovery of the prophage genome following induction.
\end{abstract}

\section{INTRODUCTION}

Earlier communications (Smith and Levine, 1966; Smith and Levine, 1967) reported the isolation of a number of integration deficient mutants of phage P22 located within a single complementation group $(L)$, 4-6 map units to the left of the $c$ region. These mutants produce turbid plaques which are indistinguishable morphologically from wild-type plaques, and on high multiplicity infection lead to cell survival. But infecting genomes are incapable of integrating as prophage and are progressively diluted among the segregating progeny cells. In mixed infections of $L$ and $L^{+}$phage, the $L^{+}$ product can act trans to carry out integration of the $L$ genome. Mutant lysogens formed by complementation are slable. The $L^{+}$gene is thus necessary for integration but not for maintenance of the lysogenic state.

1 This work was supported by U.S. Public Health Service Grant GM-09252-05.

2 Present address : Department of Microbiology, The Johns Hopkins University School of Medicine, Baltimore, Maryland 21205.
An interesting property of the $L$ lysogens was mentioned briefly in the previous report (Smith and Levine, 1967). The level of spontaneously released infectious phage in $L$ lysogen cultures is very low relative to comparable wild-type cultures. An inducing dose of UV irradiation also results in very low yields of infectious phage. Preliminary results suggested that the lysogens were being induced to produce many noninfectious phage. Results reported in this paper confirm these observations and elucidate the nature of the defect in the noninfectious particles. The particles are found to contain largely bacterial DNA rather than the normal phage genome, and the defective lysates exhibit an increased frequency of transduction for the proline $C$ locus near one end of the prophage. Possible implications of the findings for the origin of special transducing phage and for the mechanism of prophage induction are discussed.

\section{MATERIALS AND METHODS}

Phage strains. Wild-type phage P22 is designated $L^{+}$. Phage mutants $L 1$ through 
L4O have been isolated and partially described previously (Smith and Levine, 1967). The double mutant LStsc 2 used in thermal induction experiments was obtained by crossing L3 with the temperature-sensitive clear mutant $t s c_{2}$ (Levine and Smith, 1964). Plaque morphology mutants $m_{3} c_{2} h_{21}$ and $m_{3} c_{1} h_{21}$ (Levine, 1957) were used for phage and prophage crosses. Several conditional lethal $t s$ mutants were used in marker-rescue experiments. These mutants, B9, G5, B11, $B 62, B 12$, and $B 7$, are described and located on the P22 linkage map by Gough and Levine (in press, 1968). ${ }^{3}$

Bacterial strains. A derivative of Sal monella typhimurium LT-2, cured of prophage $B$ (Zinder, 1958), was used as the sensitive wild-type strain in all experiments and is designated strain 18. Lysogens $18(L 1)$ through $18(L 4 O)$ were isolated following complementation of the respective $L \mathrm{mu}$ tant with the clear, nonlysogenizing mutant $c_{2}$ or the double mutant, $c_{2} v_{1}$ (Smith and Levine, 1967). Cells were infected with a multiplicity of ten $L$ mutant phage and ten $c_{2}$ (or $c_{2} v_{1}$ ) phage. The infected cells were spread onto indicator agar and incubated at $25^{\circ}$. Individual colonies were picked into buffered saline and then streaked over a plate spread with antiphage serum $(K=3)$. After colonies had developed, an isolated colony was picked and tested for immunity and type of phage carried. The incidence of obvious double lysogens of the type $(L$, $c_{2}$ ) or $\left(L, L^{+}\right)$was about $10 \%$. Apparent single $18(L)$ lysogens were stored on slants for further study.

Heat-inducible lysogens $18\left(t s c_{2}\right)$ and 18 $\left(L 3 t s c_{2}\right)$ were used for thermal induction experiments. Recipients for transduction experiments were pro $A 15$, pro B25, pro C90 (Miyake and Demerec, 1960), his G203 (obtained from P. E. Hartman), leu 197 from the collection of Demerec, and ade 9 in the pur $E$ cistron (obtained from K. E. Sanderson). These strains were lysogenized with a P'2 sie mutant to permit transductions of normal efficiency without errors produced by the killing effects at low mul-

${ }^{3}$ The authors have changed the designations of mutants $B 9,\left({ }^{6} 6, B 11, B 62, B 12\right.$, and $B 7$ to $t s 9.1$, ts 5.1, ts 11.1, is 2.1 , ts 12.2, and $t s 3.1$, respectively. tiplicities of infection (N. Rao, in preparation). Prophage mapping experiments were performed using the Hfr strain SU576 $\mathrm{pur}$ $C 7\left(m_{3} c_{1} h_{21}\right)$ (Smith and Levine, 1965) and $\mathrm{F}^{-}$strains pro $A 15(+++)$, pro $A 15$ (B9), pro C90 (L11), and pro C90 $(+++)$. An $18 \mathrm{~T}^{-}$strain derived from 18 was used for preparation of thymine-labeled bacterial DNA. The deletion mutant pro $A B / 7$ (Miyake and Demerec, 1960; Smith and Levine, 1965) was used for preparation of labeled RNA.

Media. Phage infections and lysis of induced lysogens were carried out in either L broth (I evine, 1957) or supplemented M-9 (Smith and Levine, 1964). Phage was labeled with ${ }^{32} \mathrm{P}$ in low phosphorus medium (LP medium): Tris, $0.07 \mathrm{M}, \mathrm{pH} 7.4 ; \mathrm{NaCl}$, $0.0085 \mathrm{M} ; \mathrm{MgSO}_{4}, 0.0025 \mathrm{M} ; \mathrm{NH}_{4} \mathrm{Cl}, 0.015$ $M$; glucose, $0.2 \%$; casamino acids (Difco), $0.1 \%$. Buffered saline, nutrient agar, indicator agar, and soft agar for top layers have been previously described (Levine, 1957). Minimal agar contained $\mathrm{MgSO}_{4} \cdot 7$ $\mathrm{H}_{2} \mathrm{O}, 0.2 \mathrm{~g}$; citric acid $\cdot \mathrm{H}_{2} \mathrm{O}, 2 \mathrm{~g} ; \mathrm{K}_{2} \mathrm{HPO}_{4}, 10$ g; $\mathrm{NaNH}_{4} \mathrm{HPO}_{4} \cdot \mathrm{H}_{2} \mathrm{O}, 3.5 \mathrm{~g}$; water, 1 liter; glucose, $4 \mathrm{~g}$; bacto-agar (Difco), $20 \mathrm{~g}$.

Preparation of radioactive-labeled phage and bacteria. ${ }^{32} \mathrm{P}$-labeled phage was prepared as follows. $18(L)$ or $18\left(L^{+}\right)$cells were grown with aeration to $10^{8}$ cells $/ \mathrm{ml}$ in L.P medium and irradiated for 20 seconds at $50 \mathrm{~cm}$ distance with a 15-watt G.E. germicidal lamp. ${ }^{32} \mathrm{P}$ was added to an activity of $1 \mu \mathrm{C} / \mathrm{ml}$. The induced cells were then aerated at $32^{\circ}$ until lysis. Cell debris was removed by centrifugation at 10,000 rpm for 10 minutes in a Servall SS-34 rotor $(12,000 \mathrm{~g})$. Phage was pelleted from the supernatant by cen trifugation at $17,000 \mathrm{rpm}$ for 1 hour $(34,000$ 9). The pellet was resuspended in $1 \mathrm{ml}$ of Tris- $\mathrm{Mg}$ buffer (Tris, $0.01 \mathrm{M} ; \mathrm{MgCl}_{2}, 0.00$ ) $M, \mathrm{pH} 7.5)$. The phage suspension was incubated for 30 minutes at $37^{\circ}$ with $10 \mu \mathrm{g}$ of DNase and then purified by banding in a CsCl gradient. The phage band was collected and diluted to $1 \mathrm{ml}$ volume with Tris, $0.01 M, \mathrm{pH} 7.4$.

Thymidine ${ }^{3} \mathrm{H}$-labeled 18 cells were prepared by growth from a concentration of $10^{8}$ cells $/ \mathrm{ml}$ to approximately $4 \times 10^{8}$ cells $/ \mathrm{ml}$ at $37^{\circ}$ in supplemented $M-9$ containing 
deoxyadenosine, $200 \mu \mathrm{g} / \mathrm{ml}$, and thymidine${ }^{3} \mathrm{H}, 17.4 \mathrm{C} / \mathrm{mmole}(2.5 \mu \mathrm{C} / \mathrm{ml})$. The labeled cells were than harvested by centrifugation and washed twice with buffered saline.

Thymidine ${ }^{14} \mathrm{C}$-labeled cells were prepared utilizing the $18 T^{-}$strain. Cells from an overnight culture in supplemented M-9 plus thymidine $20 \mu \mathrm{g} / \mathrm{ml}$ were centrifuged, washed with buffered saline, and resuspended at a concentration of $5 \times 10^{7}$ cells/ $\mathrm{ml}$ in supplemented M-9 containing thymidine, $2 \mu \mathrm{g} / \mathrm{ml}$, and thymidine ${ }^{14} \mathrm{C}, 35.9 \mathrm{mC} /$ mmole $(0.025 \mu \mathrm{C} / \mathrm{ml})$. The cells were aerated at $37^{\circ}$ to a concentration of $5 \times 10^{8}$ cells $/ \mathrm{ml}$, collected by centrifugation, and washed. with buffered saline.

Thymidine- ${ }^{3} \mathrm{H}$-labeled wild-type phage was prepared by infection of 18 cells in labeled media. The cells were grown to a concentration of $10^{8}$ cells $/ \mathrm{ml}$ in supplemented M-9 and infected with phage $L^{+}$at a multiplicity of one. Simultaneously thymidine${ }^{3} \mathrm{H}, 20 \mathrm{C} / \mathrm{mmole}(10 \mu \mathrm{C} / \mathrm{ml})$, and deoxyadenosine, $200 \mu \mathrm{g} / \mathrm{ml}$, were added. Lysis occurred after 60 minutes of aeration at $37^{\circ}$. The phage was purified from the crude lysate as described above.

$D N A$ extraction procedures. Radioactive bacterial DNA was extracted as follows. The labeled, washed cells were resuspended in SSV $(0.15 M \mathrm{NaCl}, 0.1 M$ EDTA, $\mathrm{pH} 8)$ at a concentration of approximately $5 \times 10^{10}$ cells/ml. Sarkosyl (Geigy Chemical Corporation, Ardsley, New York) was added to a concentration of $1 \%$ and the cells were lysed by incubation at $65^{\circ}$ for 5 minutes. The DNA was extracted once with an equal volume of phenol saturated with SSV and the phases were separated by centrifugation at $15,000 \mathrm{rpm}$ in the Servall SS-34 rotor for 10 minutes. The aqueous phase was precipitaled with 2 volumes of $95 \%$ ethanol and the precipitate was washed in $70 \%$ and $99 \%$ ethanol. The DNA was then redissolved in one volume of $\mathrm{SSC} / 100$ (SSC $=0.15 M$ $\mathrm{NaCl}, 0.015 M$ sodium citrate). The solution was brought to $1 \times$ SSC by addition of $10 \times$ SSC. RNA was digested by incubation for 30 minutes at $37^{\circ}$ with $100 \mu \mathrm{g} / \mathrm{ml}$ RNase (heated to $100^{\circ}$ for 10 minutes to inactivate contaminating DNase) and $20 \mu \mathrm{g} / \mathrm{ml} \mathrm{T1}$ RNase (Sigma Chemical Co., St. Louis,
Missouri). Phenol extraction and ethanol precipitation were then repeated and the DNA was redissolved in one volume of $\mathrm{SSC} / 100$.

Unlabeled bacterial DNA for preparation of filters for hybridization experiments was extracted twice with phenol, precipitated once with ethanol, and redissolved in SSC/ 100. RNA contained in the preparation does not bind to nitrocellulose filters and is lost at the time of filter preparation.

Unlabeled phage DNA for preparation of filters in the hybridization experiments was extracted as follows. Phage $c_{2}$ purified by the method used for radioactive phage (optical cross section $=1.8 \times 10^{-12} \mathrm{OD}_{260} / \mathrm{PFU}$ ) was suspended in SSV at an $\mathrm{OD}_{260}$ of 10 and extracted once with an equal volume of cold SSV-saturated phenol. Phases were separated by centrifugation at $15,000 \mathrm{rpm}$ for 10 minutes. The phage DNA in the aqueous phase was then precipitated with ethanol, rinsed with $70 \%$ and $99 \%$ ethanol and redissolved in one volume of SSC/100.

Labeled-phage DNA for use in hybridization experiments and for $\mathrm{CsCl}$ or sucrose gradients was released from phage coats by $1 \%$ sarkosyl at $65^{\circ}$ for 10 minutes.

Preparation of radioactive-labeled bacterial $R N A$. Uridine- ${ }^{3} \mathrm{H}$-labeled bacterial RNA from strains 18 and pro $A B 47$ was extracted by a method similar to that described by Green (1966) except that preparations were not deproteinized by phenol extraction. Cells were grown to a concentration of $2 \times$ $10^{8}$ cells $/ \mathrm{ml}$ in $200 \mathrm{ml}$ of supplemented M-9 medium by aeration at $37^{\circ}$. The cells were then poured into a prewarmed $1000 \mathrm{ml}$ flask containing $1 \mathrm{ml}$ of uridine ${ }^{3} \mathrm{H}(22 \mathrm{C} / \mathrm{mmole}$, $0.5 \mu \mathrm{C} / \mathrm{ml}$ ) and swirled vigorously for 30 seconds. The contents were then poured onto $80 \mathrm{ml}$ of crushed ice, $2 \mathrm{ml}$ of uridine $(10 \mathrm{mg} /$ $\mathrm{ml}$ ), and $2 \mathrm{ml}$ of $1 M \mathrm{NaCN}$ in a large beaker. The cells were centrifuged and washed once with TMC (Tris $0.01 M, \mathrm{pH} 7.4 ; \mathrm{MgSO}_{4}$, $0.005 M ; \mathrm{NaCN}, 0.01 M$ ) and finally resuspended in $4 \mathrm{ml}$ of TMC containing DNase, $50 \mu \mathrm{g} / \mathrm{ml}$, and lysozyme, $200 \mu \mathrm{g} / \mathrm{ml}$. The cell suspension was frozen in an acetone-dry ice mixture, thawed at $37^{\circ}$ and placed at $15^{\circ}$ for 5 minutes. The cells were then lysed by addition of $0.4 \mathrm{ml}$ of $30 \%$ sarkosyl and incu- 
bation at $60^{\circ}$ for 10 minutes. The final RNA preparation was diluted with $20 \mathrm{ml}$ of $2 \times$ SSC

RNA-DNA hybridization. RNA was hybridized to DNA immobilized on nitrocellulose filters (Carl Schleicher \& Schuell Co., $24 \mathrm{~mm}$, type B-6 membranc filter) cssentially as described by Gillespie and Spiegelman (1965). Purified phage of known optical density at $260 \mathrm{~m} \mu$ was incubated in $0.1 N \mathrm{NaOH}$ at room temperature for 10 minutes and then neutralized to $\mathrm{pH} 8$ with $1 / 10$ volume of $\mathrm{HCl} 1.1 N$-Tris, $0.1 M$ (Studier, 1965). The released, denatured DNA was diluted 10 -fold with $2 \times$ SSC, collected on membrane filters, washed twice with $5 \mathrm{ml}$ of $2 \times$ SSC and dried at room temperature. The DNA was fixed on the filters by heating for 20 minutes under an infrared lamp. Retention of DNA on the filters was essentially quantitative. The amount of DNA in the original phage suspension was estimated from the optical density according to the formula

$\mu \mathrm{g}$ IONA $=\frac{\mathrm{OD}_{260}}{\text { optical cross section }}$

$\times \frac{\text { M.W.dna } \times 10^{6}}{\text { Avogadro's No. }}$

M.W. DNA $=28.5 \times 10^{6}$ (Studier, personal communication), and the optical cross section is $1.8 \times 10^{-12} \mathrm{OD}_{260} / \mathrm{PFU}$ so that $\mu \mathrm{g}$ $\mathrm{DNA}=26.2 \times \mathrm{OD}_{260}$.

The DNA filters were incubated with $2 \mathrm{ml}$ of ${ }^{3} \mathrm{H}$-labeled bacterial RNA plus $3 \mathrm{ml}$ of $2 \times \mathrm{SSC}$ at $60^{\circ}$ for 16 hours. The filters were rinsed with three $5-\mathrm{ml}$ washes of $2 \times$ SSC and treated for 15 minutes at $37^{\circ}$ with RNase, $7 \mu \mathrm{g} / \mathrm{ml}$. The filters were then washed on each side with five 5 -ml washes of $2 \times \mathrm{SSC}$. The dried filters were placed in vials with $5 \mathrm{ml}$ scintillation medium (PPO, $5 \mathrm{~g}$; dimethyl POPOP, $300 \mathrm{mg}$; toluene, 1 liter) and counted on a Tri-Carb scintillation spectrometer.

DNA-DNA hybridization. The membranefilter technique of Denhardt (1966) was used. Bacterial and phage DNA preparations were denatured by alkali or heat $\left(100^{\circ}\right.$ for 5 minutes). Samples of $10 \mu \mathrm{g}$ in $2 \times \mathrm{SSC}$ were fixed onto nitrocellulose filters as de- scribed above. The DNA-containing filters were than incubated for 6 hours at $65^{\circ}$ in scintillation vials with $1 \mathrm{ml}$ of polymer mixture $(0.02 \%$ each of Ficoll, polyvinyl pyrrolidone, and bovine serum albumin in $3 \times$ SSC). The labeled DNA samples to be hybridized were then added in a $0.10 \mathrm{ml}$ volume containing not greater than $0.15 \mu \mathrm{g}$ of DNA. Incubation at $65^{\circ}$ was continued for 12 hours. The filters were removed and washed on each side with five $5-\mathrm{ml}$ washes of $2 \times$ SSC, dried, and counted. The amount of nonspecific sticking of labeled DNA was generally less than $1 \%$ as determined by incubation with filters containing no DNA.

Sucrose gradients. A $0.1 \mathrm{ml}$ volume of labeled-phage DNA was layered onto a $5-\mathrm{ml}$ $5-20 \%$ sucrose gradient (Smith and lsevine, 1965) containing $0.1 \%$ sarkosyl and centrifuged in an SW 50 I. rotor at $25^{\circ}$ for $100 \mathrm{~min}$ utes at 49,000 rpm. Approximately 1005 drop fractions were collected onto $5 / 8 \times 13 \%$ inch strips of 3 MM Whatman chromatography paper. The strips were dried, placed in vials containing $15 \mathrm{ml}$ of scintillation medium, and counted.

CsCl density gradients. Labeled DNA was brought to a colume of $0.75 \mathrm{ml}$ with $0.01 M$ Tris, $\mathrm{pH} 8$, and mixed with $2.25 \mathrm{ml}$ of $65 \%$ $\mathrm{CsCl}$ in $0.01 M$ Tris, $\mathrm{pH} 8$, in $5-\mathrm{ml}$ centrifuge tubes. The tubes were overlaid with $2 \mathrm{ml}$ of mineral oil and then centrifuged in the $\mathrm{SW}$ 39 rotor at $20^{\circ}$ for 60 hours at $29,000 \mathrm{rpm}$. Sixty 5-drop fractions were collected onto paper strips and dried. The strips were washed in $10 \%$ trichloroacetic acid for 20 minutes, $5 \%$ trichloroacetic acid for 10 minutes, rinsed twice with acetone, dried, and counted as before. Ratios of activity of ${ }^{3} \mathrm{H}:{ }^{14} \mathrm{C}:{ }^{32} \mathrm{P}$ were maintained approximately at $16: 4: 1$ to facilitate separation of counts by the triple-channel scintillation spectrometer. Channel discriminators were set so that lower energy isotopes did not spill into higher energy channels.

Equilibrium banding of phage was carried out in $3 \mathrm{ml}$ of $\mathrm{CsCl}, \rho=1.50 \mathrm{~g} / \mathrm{cm}^{3}$, overlaid with $2 \mathrm{ml}$ of mineral oil. Tubes were centrifuged at $20^{\circ}$ for 24 hours at $22,000 \mathrm{rpm}$. Approximately fifty-five $;$-drop fractions were collected into small tubes for assay of radioactivity and PFU. 
UV and thermal inductions. Cells were suspended in buffered saline or supplemented M-9 medium in glass petri dishes and irradiated with UV light. Cell concentrations did not exceed $10^{8}$ cells $/ \mathrm{ml}$, nor did the depth of the cell suspension in the dish exceed $2 \mathrm{~mm}$. UV light was administered with a 15 -watt G.E. germicidal lamp at 68 cm for 20 seconds unless otherwise stated.

Lysogens carrying $t s c_{2}$-mutant prophage were stable when grown at $25^{\circ}$. Thermal induction was initiated by transfer to $40^{\circ}$.

Prophage mapping procedure. The $\mathrm{Hfr}$ strain, SU576 pur $C^{n}\left(m_{3} c_{1} h_{21}\right)$ and the $\mathrm{F}^{-}$strain pro $\mathrm{C} 90(+++)$ were grown in $\mathrm{L}$ broth to a density of approximately $5 \times 10^{8}$ cells $/ \mathrm{ml}$. A mixture of $0.4 \mathrm{ml}$ of the $\mathrm{Hfr}$ strain and $2.0 \mathrm{ml}$ of the $\mathrm{F}^{-}$strain were collected by filtration onto a sterile Millipore filter $(0.45 \mu$ pore size). The filter was incubated for 5 minutes on the surface of a soft agar layer at $37^{\circ}$ as described by Sanderson and Demerec (1965). The filter containing the mating cells was then placed in an aeration tube containing $20 \mathrm{ml}$ of $\mathrm{L}$ broth and aerated gently to early stationary phase. Proline recombinants were selected in minimal medium by diluting $0.05 \mathrm{ml}$ of the L-broth culture into $100 \mathrm{ml}$ of nonsupplemented M-9 and aerating overnight to stationary phase. Recombinants were further selected by diluting $0.05 \mathrm{ml}$ of this culture into $10 \mathrm{ml}$ of M-9 and aerating for 2 hours. The $\log$ phase cells at approximately $5 \times 10^{7}$ cells $/ \mathrm{ml}$ were diluted by a factor of $10^{4}$ into supplemented M-9 and induced by UV light. Infective centers were plated on indicator agar. After incubation overnight at $37^{\circ}$ the various prophage genotypes were recorded. Other prophage crosses were performed similarly.

Transduction. CsCl-purified phage lysates from UV-induced $18(L 11)$ and $18\left(L^{+}\right)$ lysogens were made as described under preparation of ${ }^{32} \mathrm{P}$-labeled phage, except that no label was used. CsCl-purified $L^{+}$and $L 11$ phage lysates were also obtained by infection of 18 cells as described under preparation of ${ }^{3} \mathrm{H}$-labeled phage but without use of label. The absolute number of particles in each purified phage suspension was estimated from the optical density at $260 \mathrm{~m} \mu$ and the known optical cross section. Transductants were assayed by plating a mixture of $0.1 \mathrm{ml}$ of the recipient bacterial cells and $0.1 \mathrm{ml}$ of the appropriately diluted phage suspension on minimal agar plates. Transductant colonies could be counted after 24 hours of incubation at $37^{\circ}$.

Marker rescue. Defective particles from $L$ mutant lysates which do not produce infective centers were absorbed to sensitive cells and superinfected with various $t s$ mutants which do not yield infective centers when plated at $37^{\circ}$. If the defective particle DNA contains the $t^{+}$marker and can recombine then $t s^{+}$phage will be produced and some of the mixedly infected cells will become infective centers. Sensitive 18 cells were grown with aeration in $\mathrm{L}$ broth to $2 \times 10^{8}$ cells $/ \mathrm{ml}$. One-tenth milliliter of cell suspension was added to $0.1 \mathrm{ml}$ of defective phage suspension (containing approximately $2 \times 10^{3} \mathrm{PFU} / \mathrm{ml}$ and $1 \times 10^{7}$ particles $/ \mathrm{ml}$ ) and incubated at room temperature to permit absorption. After 5 minutes, the cells were superinfected with $0.1 \mathrm{ml}$ of $t s$ mutant suspension $\left(4 \times 10^{9}\right.$ phage $/ \mathrm{ml}$ ). After an additional 5 minutes of absorption, the infected cells were diluted with $2 \mathrm{ml}$ of $\mathrm{L}$ broth and $0.1 \mathrm{ml}$ was plated for infective centers on nutrient agar. As a control noninfectious phage containing all phage markers, $L^{+}$phage which had been UV-treated to a survival of $10^{-4}$ was used.

Morphological markers were reseued by performing a cross $(L+++) \times\left(+m_{3}\right.$ $c_{2} h_{21}$ ) and determining the frequency of $m_{3}{ }^{+}, c_{2}{ }^{+}$, and $h_{21}{ }^{+}$among the progeny phage. One-tenth milliliter of 18 cells at $2 \times 10^{8}$ cells $/ \mathrm{ml}$ were infected with $0.1 \mathrm{ml}$ of defective lysale $\left(4 \times 10^{5} \mathrm{PFU} / \mathrm{ml}\right.$ and approximately $2 \times 10^{9}$ particles $/ \mathrm{ml}$ ). After 5 minutes $0.1 \mathrm{ml}$ of phage $m_{3} c_{2} h_{21}\left(2 \times 10^{9}\right.$ $\mathrm{PFU} / \mathrm{ml}$ was added. At 10 minutes the infected cells were diluted by a factor of $2 \times$ $10^{4}$ and incubated for 90 minutes at $37^{\circ}$. After chloroform treatment, progeny phage were plated on indicator plates. The plates were incubated overnight at $37^{\circ}$ and then scored for the various genotypes. As before 
UV-treated $L^{+}$phage was used for a control infection with $m_{3} c_{2} h_{21}$ phage.

\section{RESULTS}

\section{Induction of L Mutant Lysogens}

Table 1 gives a tabulation of the relative yield of each mutant lysogen per UV-irradiated cell at $25^{\circ}$ and $37^{\circ}$ as compared to that from the wild-type lysogen. For descriptive purposes the mutants can be grouped into four classes with respect to relative PFU yicld at low and high tempcrature. Class I mutants (L2, 3, 11, 17, 18, 27, 32) give very low yields at both $25^{\circ}$ and $37^{\circ}$. Class II mutants $(L 4,6,15,29,33,37)$ give nearly normal yield at both $25^{\circ}$ and $37^{\circ}$. Class III mutants are intermediate in yield at $37^{\circ}$ and fall into two groups $\mathrm{A}$ and B. Group A mutants $(L 14,20,22,28$, 39) are also intermediate in yield at $25^{\circ}$ and consequently show very little temperature differential. Group B mutants ( $L 1$, $10,12,16,25,36,38)$ show essentially normal yields at $25^{\circ}$ and thus possess moderately high $\left(25^{\circ}\right.$ yield $) /\left(37^{\circ}\right.$ yield $)$ ratios. These mutants comprise the entire group of mutants temperature-sensitive for integration efficiency (Smith and Levine, 1967). Class IV mutants $(L 7,9,13,19,23,24,26$, $30,31,34,40)$ show low yields at $37^{\circ}$ and nearly normal yields at $25^{\circ}$. They are thus markedly temperature sensitive with respect to PFU yield. These mutants, however, show no temperature sensitivity with respect to integration efficiency.

Class II lysogens require special comment as they fail to show the property of low yield at either temperature. The phage released spontaneously from these lysogens were of $L$ phenotype thus ruling out $L, L^{+}$ double lysogens as a reason for the high yield. Seventy-nine additional independent $L 4$ lysogens were isolated from a mixed infection with $m_{3} c_{2} h_{21}$ phage. Among these were three obvious doubles producing mottled infective centers: 5 were high yielders, and 71 were low yielders. From this it is clear that the $18(L / 4)$ lysogen originally isolated and included in class II of Table 1 is an exception. Also eight additional 215 lysogens were isolated from mixed infection with $m_{3} c_{2} h_{21}$ phage; and, of these, 2 were doubles of the type $L, c_{2}$ and 6 were high
TABLE 1

Relative Yields of $18(L)$ Lysogens after UV IRRADIATION AT $25^{\circ}$ AND $37^{\circ}$

\begin{tabular}{|c|c|c|c|c|}
\hline \multirow{2}{*}{$\begin{array}{l}\text { Class and } \\
\text { group }\end{array}$} & \multirow{2}{*}{$\begin{array}{c}\text { Lysogen } \\
\text { number }\end{array}$} & $\begin{array}{l}\text { Yield o } \\
\text { relative } t\end{array}$ & $\begin{array}{l}\mathrm{PFU} / \text { cell } \\
\text { wild type }\end{array}$ & \multirow{2}{*}{ 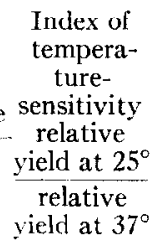 } \\
\hline & & $25^{\circ}$ & $37^{\circ}$ & \\
\hline \multirow{9}{*}{$\begin{array}{l}\text { Wild type } \\
\text { Class I }\end{array}$} & $L^{+}$ & 1.0 & 1.0 & 1.0 \\
\hline & 122 & 0.0092 & 0.0020 & 4.6 \\
\hline & $L G$ & 0.0012 & 0.0026 & 0.5 \\
\hline & $L .5$ & 0.010 & 0.0025 & 4.0 \\
\hline & $L 11$ & 0.0019 & 0.0039 & 0.5 \\
\hline & $L 1 \gamma$ & 0.0004 & 0.0009 & 0.5 \\
\hline & $L 18$ & 0.0001 & 0.0001 & 1.0 \\
\hline & $L \% 7$ & 0.0005 & 0.0010 & 0.5 \\
\hline & L32 & 0.0010 & 0.0009 & 1.1 \\
\hline \multirow[t]{6}{*}{ Class II } & $L 4$ & 2.4 & 10.0 & 0.2 \\
\hline & 16 & 0.58 & 0.80 & 0.7 \\
\hline & $L 15$ & 0.14 & 0.09 & 1.5 \\
\hline & $L 29$ & 0.55 & 0.95 & 0.6 \\
\hline & L33 & 0.66 & 0.75 & 0.9 \\
\hline & $L B 7$ & 0.92 & 2.1 & 0.4 \\
\hline
\end{tabular}

Class III

$\begin{array}{llllr}\text { Group A } & \text { L14 } & 0.24 & 0.037 & 6 \\ & L 20 & 0.15 & 0.013 & 11 \\ & \text { L22 } & 0.072 & 0.015 & 5 \\ & L 28 & 0.40 & 0.076 & 5 \\ & L 99 & 0.053 & 0.024 & 2 \\ \text { Group B } & L 1 & 2.1 & 0.17 & 12 \\ & L 10 & 1.0 & 0.018 & 55 \\ & L 12 & 1.0 & 0.010 & 100 \\ & L 16 & 1.0 & 0.050 & 20 \\ & L 25 & 0.15 & 0.0014 & 110 \\ & L 36 & 1.1 & 0.11 & 10 \\ & L 38 & 0.86 & 0.014 & 61 \\ \text { Ilass IV } & L 7 & 1.1 & 0.014 & 79 \\ & L 9 & 0.46 & 0.0010 & 160 \\ & L 19 & 0.48 & 0.0008 & 600 \\ & L 19 & 0.51 & 0.0006 & 850 \\ & L 23 & 0.45 & 0.0036 & 120 \\ & L 24 & 0.13 & 0.0033 & 40 \\ & L 26 & 0.56 & 0.0028 & 200 \\ & L 30 & 0.20 & 0.0002 & 1000 \\ & L 31 & 0.53 & 0.0018 & 300 \\ & L 34 & 0.74 & 0.010 & 74 \\ & L 40 & 0.28 & 0.0019 & 150 \\ & & \end{array}$

${ }^{a}$ Each lysogen was assayed for cell concentration and then induced by UV irradiation. Aliquots were incubated at $25^{\circ}$ and $37^{\circ}$ until lysis, treated with chloroform, and then assayed for PFU. Yields per cell were divided by the wild type yield per cell to facilitate relative comparisons. 


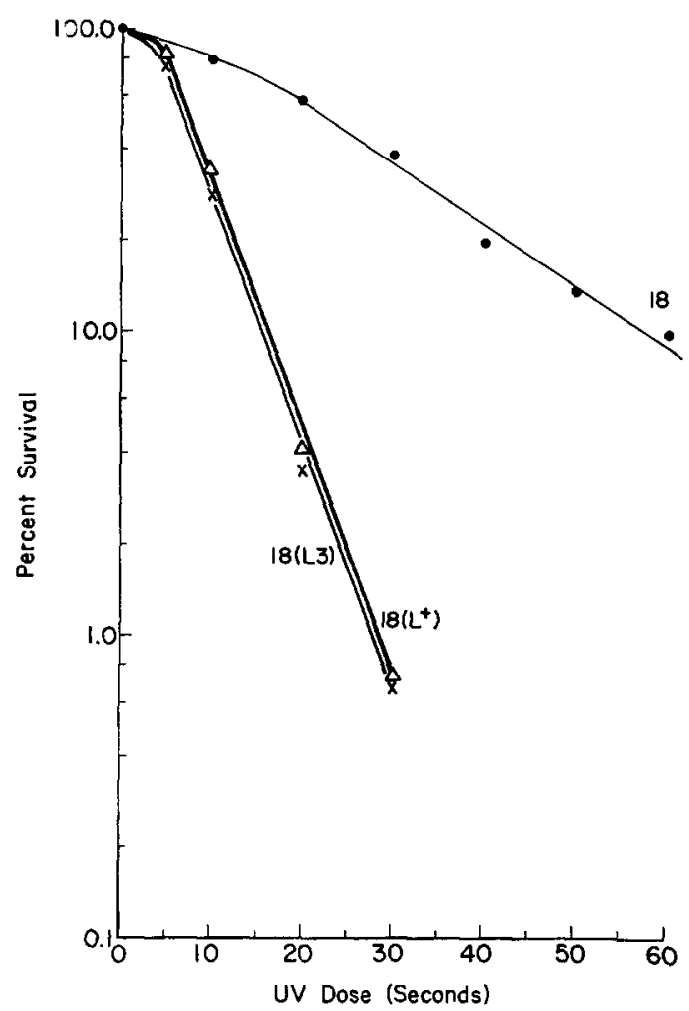

FIG. 1. UV survival curves for nonlysogenic 18 cells and for the mutant lysogen $18(I B)$ and the wild-type lysogen $18\left(L^{+}\right)$.

yielders. It is apparent that $L$ mutants are prone to formation of stable double lysogens, in contrast to wild-type phage which rarely forms double lysogens. For comparison, 100 lysogens were isolated from a mixed infection of wild-type and $m_{3} c_{2} h_{21}$ phage. No stable double lysogens were found.

It seems likely that the high yielders of class II which release only $L$ phage are in reality $18(L, L)$ double lysogens; this possibility will be considered further in the discussion.

In general the yield of infectious phage following UV treatment of $L$ lysogens is low. Three possible reasons for this exist. (1) The mutant prophage are not inducible by UV irradiation. (2) Induction occurs, but total phage production is markedly reduced. (3) Phage production is normal, or near normal, but most of the particles are noninfectious.

Identical killing curves are obtained by UV irradiation for both $18(L S)$ and $18\left(L^{+}\right)$
(Fig. 1). Control nonlysogenic 18 cells are considerably more resistant to UV treatment. By this criterion, $18(L 3)$ is normally inducible. The mutant lysogens also induce thermally. Lysogen $18\left(L 3 t s c_{2}\right)$, grown to $10^{8}$ cells $/ \mathrm{ml}$ at $25^{\circ}$ and then thermally induced by transfer to $40^{\circ}$, lyses almost completely after a latent period of about 60 minutes (Fig. 2). Induction of the control lysogen, $18\left(t s c_{2}\right)$, proceeds with the same kinetics. Similar lysis curves are obtained following UV treatment sufficient to kill $95 \%$ or more of the cells.

Total phage particle production is only moderately reduced in induced mutant lysogens as compared to $18\left(L^{+}\right)$(Table 2). The phage lysates obtained from the thermal induction experiment of Fig. 2 were concentrated and banded in $\mathrm{CsCl}$. In both cases visible bands were seen at approximately the same position, and the total yields of particles assayed by $\mathrm{OD}_{260}$ differed only by a factor of 2. However, the mutant infectious yield was reduced by a factor of $10^{5}$. Similarly, UV induction yielded only moderately reduced total particles while infectious yield was lowered by several decades. The lysates thus consist predominantly of noninfectious (defective) phage.

The remainder of this report deals whih the nature of the noninfectious particles and the manner of their origin.

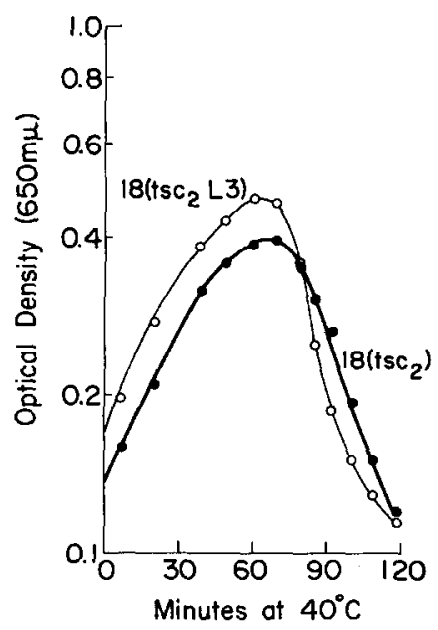

Fig. 2. Thermal induction of $18\left(t s \mathrm{c}_{2}\right)$ and $18\left(t s c_{2} L S\right)$ at $40^{\circ}$ as followed by optical density. 
TABLE 2

Infective Yield (PFU/mL) versus Total Particle Yield $\left(\mathrm{OD}_{260} \mathrm{~m} \mu / \mathrm{CM}\right)$ from Induced Lysochens ${ }^{a}$

\begin{tabular}{|c|c|c|c|c|}
\hline Method of induction & Lysogen & $\mathrm{OD}_{260 \mathrm{~m} \mu} / \mathrm{cm}$ & $\mathrm{PFU} / \mathrm{ml}$ & $\mathrm{PFU} / \mathrm{OD}_{3 \mathrm{fin}} \mathrm{m \mu}$ \\
\hline \multirow[t]{3}{*}{ Ultraviolet light } & $18\left(L^{+}\right)$ & 0.686 & $1.3 \times 10^{10}$ & $1.9 \times 10^{10}$ \\
\hline & $18(L B)$ & $0.17 t$ & $3 \times 10^{5}$ & $1.7 \times 10^{6}$ \\
\hline & $18(1.11)$ & 0.380 & $2.4 \times 10^{7}$ & $0.3 \times 10^{i}$ \\
\hline \multirow[t]{2}{*}{ Thermal $40^{\circ}$} & $18\left(t s c_{2}\right)$ & 4.83 & $1.3 \times 10^{11}$ & $2.7 \times 10^{10}$ \\
\hline & $18\left(1,3 t s c_{2}\right)$ & 2.90 & $5 \times 10^{5}$ & $1.7 \times 10^{5}$ \\
\hline
\end{tabular}

a Optical density at $260 \mathrm{~m} \mu$ wavelength and $\mathrm{PFU} / \mathrm{ml}$ were measured on CsCl-purified lysates of induced lysogens. The ratio $\mathrm{PFU} / \mathrm{OD}_{260}$ gives a measure of the viability of the phage suspensious.

\section{Single-Burst Experiments}

Is the induced population of cells behaving uniformly or does a small fraction of the population contribute nearly all of the infectious particles? $18\left(L^{+}\right), 18(L 4), 18(L 15)$, and $18(L 11)$ were induced with UV light and distributed in tubes at less than one infectious center per tube. A tabulation of the single bursts is shown in Table 3 . The null class is greater than one-half, indicating that, in general, single bursts are being observed. The control wild-type lysogen $18\left(L^{+}\right)$shows considerable variability in burst size (35-1174) with an average burst of 336 . The mutant $18(L / 4)$ was included because it produces exceptionally high yields relative to wild-type (Table 1 ). The single bursts are also large on the average, but some very low bursts were observed. 18(L15) produces reduced burst sizes commensurate with its reduced relative yield, and $18(L 11)$ is even more extreme. The average burst size of 3.7 per infective center is not a fair comparison for $18(L 11)$ because more than 40 induced cells per tube were necessary to to yield one infectious phage-producing cell; i.e., the majority of cells produce only non-infectious particles in this case. From these data it is clear that low yield of infectious phage is a result of low yield in individual cells. The distribution is not a bimodal one with a few high-yielding cells among many non-yielding cells.

The particles produced by induction of the $L$ lysogens could be noninfectious because of either an abnormal capsid or a defective genome. The former would include alterations of structure interfering with adsorption or injection. The latter would include incomplete phage genomes or re- placement with bacterial DNA as in transducing particles. $L$ mutants are deficient in ability to integrate intracellular phage DNA as prophage. As a working hypothesis it seemed likely that the "reverse" process of retrieval of prophage DNA from the bacterial genome following induction might be faulty. Therefore experiments were aimed at the DNA content and genetic content of the particles.

\section{Phage Density in $\mathrm{CsCl}$}

A ${ }^{32} \mathrm{P}$-labeled preparation of $L 1 t$ particles obtained by UV induction was saturated with phage tail parts to eliminate density variations from phage with absent or incomplete tails (Israel et al., 1967) (see legend to Fig. 3). The labeled phage were then centrifuged to equilibrium in $\mathrm{CsCl}$. The radioactive peak was significantly more dense $(\Delta \rho=0.0023)$ than the PFU peak representing the small fraction (approximately $10^{-3}$ ) of "normal" infectious phage in the preparation (Fig. 3). Thus the defective particles which constitute at least $99.9 \%$ of the preparation are of greater density than normal. This density shift, if due to DNA content, could be accounted for by either (a) increased total amount of DNA in the phage head; or (b) increased GC content. Experience with $\lambda d l g$ phage (Weigle et al., 1959) where phage density variations were accounted for largely by DNA size variation, suggested that possibility (a) was more likely. If the size of the DNA is increased in the defective phage heads, then DNA sedimentation rate should be increased but density of DNA in $\mathrm{CsCl}$ should not be altered; whereas if increase $\mathrm{GC}$ content is the reason for the increment 
TABLE 3

Tabulation of Single Bursts from UV-Inducen Lysogens ${ }^{a}$

\begin{tabular}{|c|c|c|c|c|}
\hline & $18\left(L^{+}\right)$ & $18(L 4)$ & $18(L 15)$ & $18(L 11)$ \\
\hline & $0(37)$ & $0(31)$ & $0(34)$ & $0(33)$ \\
\hline & 35 & 1 & 1 & 1 \\
\hline & 65 & 1 & 1 & 1 \\
\hline & 71 & 35 & 2 & 1 \\
\hline & 177 & 70 & 9 & 1 \\
\hline & 185 & 118 & 10 & 1 \\
\hline & 217 & 161 & 11 & 1 \\
\hline & 224 & 208 & 12 & 1 \\
\hline & 273 & 370 & 15 & 2 \\
\hline & 375 & $53 \check{5}$ & 19 & 2 \\
\hline & 404 & 582 & 22 & 2 \\
\hline & 417 & 665 & 23 & 2 \\
\hline & 432 & 676 & 46 & 3 \\
\hline & 485 & 722 & 54 & 3 \\
\hline & 513 & 823 & 56 & 5 \\
\hline & 1174 & 936 & 62 & 5 \\
\hline & 一 & 1041 & 97 & 5 \\
\hline & - & 1081 & 198 & 7 \\
\hline & 一 & 1129 & - & 7 \\
\hline & - & 1385 & - & 21 \\
\hline & - & 1776 & 一 & 一 \\
\hline Total plaques & 5047 & 12,315 & 638 & 71 \\
\hline $\begin{array}{l}\text { Average burst size (total plaques/ } \\
\text { number of plates containing } \\
\text { bursts) }\end{array}$ & 336 & 615 & 37.5 & 3.7 \\
\hline Cells/tube & 0.50 & 1.1 & 0.69 & 41 \\
\hline Infective center/tube & 0.29 & 0.38 & 0.32 & 0.37 \\
\hline Average yield/UV-treated cell & 194 & 215 & 17.8 & 0.033 \\
\hline Average yield relative to wild type & 1.0 & 1.1 & 0.092 & 0.00017 \\
\hline
\end{tabular}

a The lysogens were assayed for cell concentration, given an inducing dose of UV light, assayed for infectious centers, diluted, and distributed at about 0.35 infectious centers per tube. Tubes were incubated at $32^{\circ}$ for 3 hours and then plated for infectious phage. Expected classes according to the Poisson distribution were: null class, $\left(p_{0}=0.70\right.$; single bursts, $p_{1}=0.25$; and multiple bursts, $1-\left(p_{0}+p_{1}\right)=$ 0.05 .

in phage density, then the DNA should be greater in density on a $\mathrm{CsCl}$ gradient, and sedimentation rate should be the same as that of normal phage DNA.

\section{Sedimentation Rate of Defective Phage DNA}

${ }^{32}$ P-labeled defective L11 DNA and ${ }^{3} \mathrm{H}$ labeled wild-type phage DNA were sedimented together in a sucrose gradient in an attempt to resolve a size difference (Fig. 4). The two DNA peaks appear to coincide on inspcction, and furthermore the ratio ${ }^{3} \mathrm{H}:{ }^{32} \mathrm{P}$ across the peaks is essentially constant (Fig. 4, top), To give an idea of what increment in DNA size might be detected, the ratio ${ }^{3} \mathrm{H}:{ }^{32} \mathrm{P}$ is also plotted on the assumption that the ${ }^{32} \mathrm{P}$ DNA sedimented one fraction more rapidly. This would correspond to an increase in molecular weight of $1-(72 / 71)^{1 / 0.35}=0.038$ (Burgi and Hershey, 1963). The DNA molecular weight necessary to account for the increase in phage density of $0.0023 \mathrm{~g} / \mathrm{cm}^{3}$ would be approximately 0.023 (Weigle el al., 1959). This increment in density should have been detectable if present. However, no gradient of ratios was observed across the peaks, so the defective DNA is of essentially normal size. 


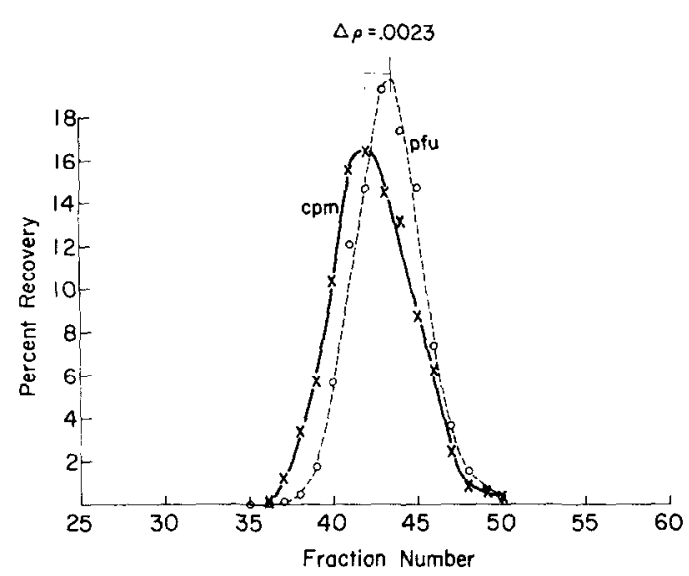

FIG. 3. Density of ${ }^{32}$ P-labeled $L 11$ defective particles in $\mathrm{CsCl}$. Approximately $2 \times 10^{7}$ defective particles were incubated overnight in 0.1 $\mathrm{ml}$ of $0.01 M$ Tris pH 7 with $10^{9}$ tail equivalents, an amount sufficient to activate all tailless phage. $\mathrm{CsCl} 65 \%$ and Tris buffer were added to a final volume of $3.0 \mathrm{ml}$ and density of 1.50 . Equilibrium banding was carried out at $22,000 \mathrm{rpm}$ for 24 hours at $20^{\circ}$ in the $\mathrm{SW} 39$ rotor. Fractions were assayed for $\mathrm{cpm}$ and for PFU. Total $\mathrm{cpm}=1870$, total PFU $=2 \times 10^{4}$. Data are plotted as percentage recovery. The density shift was calculated from the equation $\beta(\rho)(\Delta \rho / \Delta r)=\omega^{2} r$ (Ifft et al, , 1961) where $\beta(\rho)=1.245 \times 10^{9}, r=7.67 \mathrm{~cm}, \Delta r=0.71$ $\mathrm{cm}$, and $\omega=$ the angular velocity in $\mathrm{radian} / \mathrm{sec}$.
Density of Defective DNA in $\mathrm{CsCl}$

${ }^{32} \mathrm{P}$-labeled defective L11 DNA was compared with ${ }^{14} \mathrm{C}$-labeled 18 cell DNA and ${ }^{3} \mathrm{H}$-labeled $L^{+}$phage $\mathrm{DNA}$ in a $\mathrm{CsCl}$ density gradient. Bacterial DNA is 0.0035 $\mathrm{g} / \mathrm{cm}^{3}$ more dense than phage DNA. The defective L11 DNA peak closely follows that of the bacterial DNA with only a shoulder corresponding to phage DNA density (Fig. 5).

The increase in density of the defective phage DNA is approximatcly sufficient to account for the observed density increase in the phage. Since the phage composition is $50 \%$ DNA an increment of $0.0035 \mathrm{~g} / \mathrm{cm}^{3}$ in the density would cause $0.0018 \mathrm{~g} / \mathrm{cm}^{3}$ increase in phage density. Thus increased $\mathrm{GC}$ content rather than greater molecular size accounts for the observed increase in phage density. It would appear that a large portion of the total DNA content of the particles is bacterial in origin. Before proceeding to the next sections it will be convenient to establish the order of genes within the prophage and the relative positions of some nearby bacterial genes. The relationships will be shown to be of im

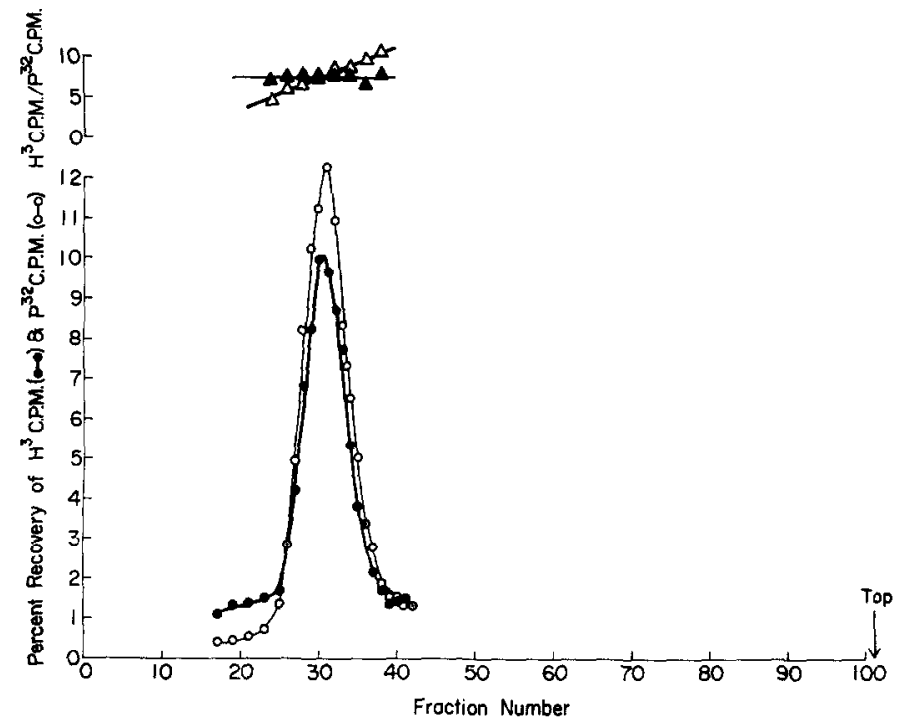

FIg. 4. Zone sedimentation of ${ }^{32} \mathrm{P}$-labeled defective $L 11$ DNA and ${ }^{3} \mathrm{H}$-labeled $L^{+}$DNA on a sucrose $5-20 \%$ gradient at $49,000 \mathrm{rpm}$ for 100 minutes at $25^{\circ}$. Total ${ }^{3} \mathrm{H} \mathrm{cpm}=7160,{ }^{32} \mathrm{P} \mathrm{cpm}=1200$. Filled triangles represent the ratio of ${ }^{3} \mathrm{H} \mathrm{cpm}$ to ${ }^{32} \mathrm{P} \mathrm{cpm}$ across the peak. Open triangles represent hypothetical ratios of ${ }^{3} \mathrm{H}$ to ${ }^{32} \mathrm{P}$ if the ${ }^{32} \mathrm{P}$ peak had sedimented one tube more rapidly. 


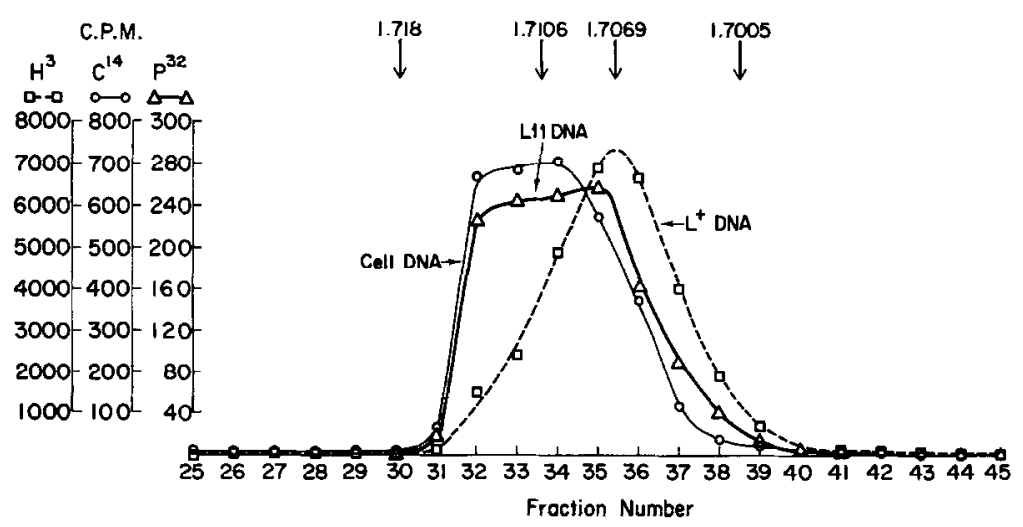

Fig. 5. Equilibrium banding of ${ }^{3} \mathrm{H}$-labeled $L^{+} \mathrm{DNA},{ }^{32} \mathrm{P}-\mathrm{labeled} L 11 \mathrm{DNA}$, and ${ }^{14} \mathrm{C}$-labeled cell DNA in $\mathrm{CsCl}$ at $29,000 \mathrm{rpm}$ for 65 hours at $25^{\circ}$. S. marcescens DNA $(\rho=1.718)$ and T4 phage DNA $(\rho=1.7005)$ were used as density references and the peak positions are marked by arrows. The density values for cell DNA and phage DNA were calculated assuming a linear gradient between the two reference DNA peaks.

portance in understanding the origin of the defective phage.

\section{Mapping of the Prophage and Adjacent Bac- terial Genes}

It was previously established that the morphological phage markers, ordered as $m_{3}-c_{1}-h_{21}$ in the vegetative state, are permuted to the order $m_{3}-h_{21}-c_{1}$ in the prophage state (Smith and Levine, 1965). This presumably occurs by cleavage of the circularized genome between $m_{3}$ and $c_{1}$ as the genome becomes inserted into the bacterial chromosome (Campbell, 1962). Furthermore, the pro $A$ and pro $B$ bacterial cistrons were located close to the $c_{1}$ end of the prophage with pro $A$ ncarest to $c_{1}$ (Fig. 6).

Additional mapping experiments were performed to determine the location of pro $C$ with respect to the prophage (Table 4 , Cross I). The data indicate that pro $C$ is nearest to $m_{3}$ and on the opposite end of the prophage from pro $A$ and pro $B$. For example, the $+c_{1} h_{21}$ recombinants should predominate if pro $C$ is nearest to $c_{1}$ (as is the case with pro $A$, Table 4 , Cross II), whereas in fact the $m_{3}++$ class predominates as expected for a location nearest to $m_{3}$. Moreover pro $C$ is significantly more distant from $c_{1}$ than from $m_{3}(P<0.05)$. For pro $A$, the distances are reversed; pro $A$ is much closer to $c_{1}$ than to $m_{3}(P<0.001)$
The order of markers is thus pro $C, m_{3}, h_{21}$, $c_{1}$, pro $A$, pro $B$ (Fig. 6 ).

The order of additional markers in the prophage can be inferred from the vegetative map of P22 and from the known placement of the prophage ends between $m_{3}$ and $c_{1}$. Recently Gough and Levine (in press, 1968) have shown that the vegetative map is circular and have located a number of temperature-sensitive mutants relative to the morphological markers $m_{3}, c_{1}$, and $h_{21}$ on the map. In Fig. 6 these $t s$ mutants are placed in their expected position on the prophage map.

Since both ts $B 9$ and $L$ are within the $m_{3}-$ $c_{1}$ region where the prophage ends are located, it was necessary to further define the position of these markers on the prophage. For example, if the prophage attachment site is between $B 9$ and $L$, then $B .9$ should map at one end of the prophage near to $m_{3}$ and $L$ should map at the opposite end near to $c_{1}$.

The cross SU576 pur Cy $\left(m_{3} c_{1} h_{21}\right) \times$ $\mathrm{F}^{-}$pro $A 15$ (B9) was performed and prot recombinants were scored for prophage type at $37^{\circ}$, the restrictive temperature for B9. The data (Table 5, Cross III) show a marked reduction of the $m_{3}^{+}$classes $+++,+c h,+c+$ and $++h$ as expected for a location of $B 9$ near to $m_{3}{ }^{+}$.

The $L$ gene was mapped by scoring prophage types in pro $^{+}$recombinants from the cross SU576 pro $C 7\left(\begin{array}{llll}m_{3} & c_{1} & h_{21}\end{array}\right) \times \mathrm{F}^{-}$ 


\section{LINKAGE MAP OF PHAGE P22}

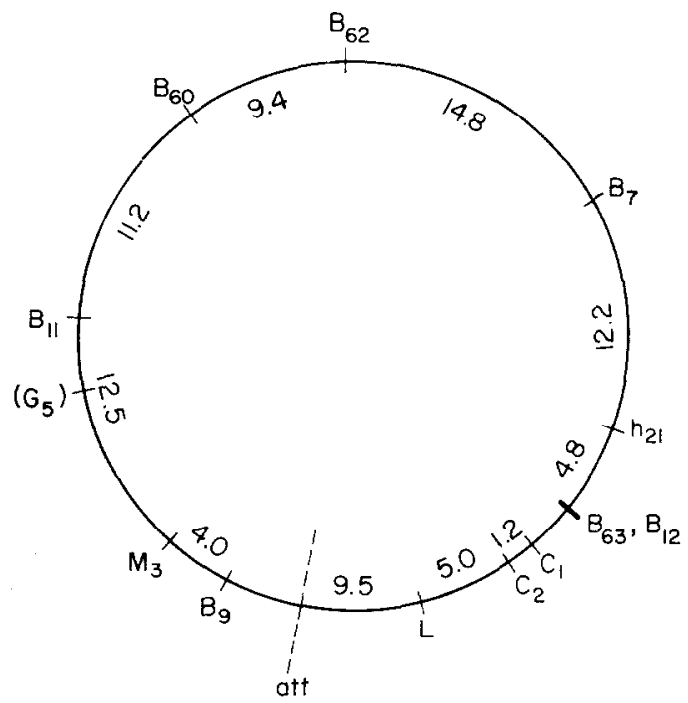

LINKAGE MAP OF PROPHAGE P 22

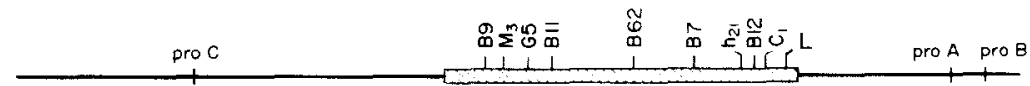

\section{LINKAGE MAP OF SALMONELLA TYPHIMURIUM}

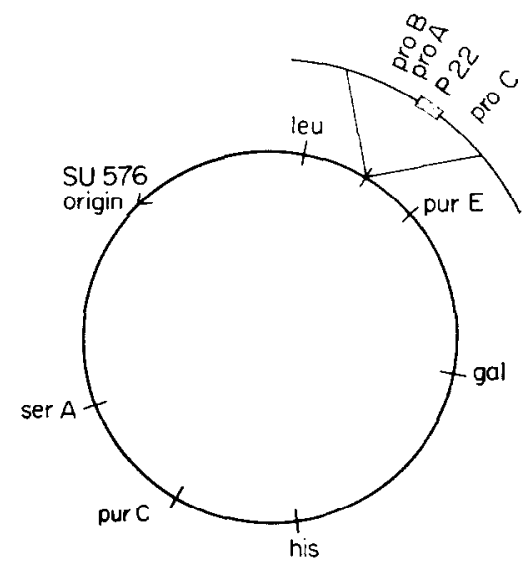

FIG. 6. Linkage relationships for phage P22 and prophage P22. The position of prophage P22 on the Salmonella typhimurium chromosome is shown in relation to the origin of the Hfr strain used in bacterial crosses and to some of the bacterial markers used in transduction experiments. The orientation of the proline region is not known with certainty.

pro C90 (L11). Since there is a marked reduction in infective conters from induc tion of $L 11$ prophage. a close linkage to $c_{1}{ }^{+}$should reduce the $c_{1}{ }^{+}$classes +++ , $m++, m+h$, and $++h$. The results (Table 5, Cross IV) indicate that $L 11$ is near to $c_{1}{ }^{+}$. The prophage attachment site is between $B 9$ and $L$ as shown in Fig. 6 .
For convenience the opposite ends of the prophage will be referred to as the $m$ end and $c$-end.

\section{RNA-DNA Hybridization Experiments}

In order to confirm that the DNA of the defective particles is in part bacterial in origin, hybridization experiments were per- 
TABLE 4

Frequencies of Prophage Genotypes Obtained from Crosses I and II ${ }^{a}$

\begin{tabular}{|c|c|c|c|c|c|c|}
\hline \multirow{2}{*}{ Genotypes } & \multicolumn{3}{|c|}{ Cross I } & \multicolumn{3}{|c|}{ Cross II } \\
\hline & Number & Percent & $\begin{array}{c}\text { Expected } \\
\text { percent }\end{array}$ & Number & Percent & $\begin{array}{c}\text { Expected } \\
\text { percent }\end{array}$ \\
\hline$m c h$ & 1365 & 48.6 & 49.3 & 1581 & 62.0 & 63.8 \\
\hline+++ & 1056 & 37.6 & 36.3 & 352 & 13.8 & 10.5 \\
\hline$+c h$ & 92 & 3.3 & 4.6 & 364 & 14.3 & 16.3 \\
\hline$m++$ & 196 & 7.0 & 6.2 & 78 & 3.1 & 2.7 \\
\hline$m+h$ & 45 & 1.6 & 1.8 & 22 & 0.8 & 0.7 \\
\hline$+c+$ & 31 & 1.1 & 1.3 & 112 & 4.4 & 4.6 \\
\hline$m c+$ & 13 & 0.5 & 0.2 & 25 & 1.0 & 1.2 \\
\hline$++h$ & 12 & 0.4 & 0.2 & 20 & 0.8 & 0.2 \\
\hline Totals & 2810 & 100.1 & 99.9 & 2554 & 100.2 & 100.0 \\
\hline
\end{tabular}

${ }^{a}$ Cross I: SU576 pur $C \gamma\left(m c_{1} h\right) \times \mathrm{F}^{-}$pro $C 90(+++)$

Cross II: SU576 pur $C 7\left(m c_{1} h\right) \times \mathrm{F}^{-}$pro $A 15(+++)$

Crosses were performed as described under methods. Expected percentages for cross II were taken from Smith and Levine (1965) and the method of computation is given there. Expected percentages for cross I were computed by the same method.

TABLE 5

Frequencies of Prophage Genotypes Obtained from Crosses III and IV

\begin{tabular}{|c|c|c|c|c|c|c|}
\hline \multirow{3}{*}{ Genotypes } & \multicolumn{4}{|c|}{ Cross III } & \multicolumn{2}{|c|}{ Cross IV } \\
\hline & \multicolumn{2}{|c|}{$25^{\circ}$} & \multicolumn{2}{|c|}{$37^{\circ}$} & \multirow{2}{*}{ Number } & \multirow{2}{*}{ Percent } \\
\hline & Number & Percent & Number & Percent & & \\
\hline$m c h$ & 1291 & 70.7 & 3392 & 91.8 & 1872 & 77.6 \\
\hline+++ & 198 & 10.9 & 40 & 1.08 & 230 & 9.54 \\
\hline$+c h$ & 200 & 11.0 & 62 & 1.67 & 150 & 6.22 \\
\hline$m++$ & 29 & 1.6 & 103 & 2.79 & 60 & 2.50 \\
\hline$m+h$ & 19 & 1.0 & 37 & 1.00 & 16 & 0.66 \\
\hline$+c+$ & 61 & 3.3 & 4 & 0.11 & 52 & 2.16 \\
\hline$m c+$ & 22 & 1.2 & 55 & 1.49 & 18 & 0.75 \\
\hline$++h$ & 5 & 0.3 & 1 & 0.03 & 13 & 0.54 \\
\hline Totals & 1825 & 100.0 & 3694 & 99.97 & 2411 & 99.97 \\
\hline
\end{tabular}

${ }^{a}$ Cross III: SU576 pur $C 7\left(m_{3} c_{1} h_{21}\right) \times \mathrm{F}^{-}$pro $A 15(B 9)$

Cross IV: SU576 pur $C^{\prime} 7\left(m_{3} c_{1} h_{21}\right) \times \mathrm{F}^{-}$pro $C 90(L 11)$

Comparative data at $25^{\circ}$ and $37^{\circ}$ are given for cross 1 II to show the change in $m_{3}+$ classes at the restrictive temperature for $t s B 9$. Cross IV data must be compared to cross I frequencies to show the effect of $L 11$ on the morphological classes.

formed. ${ }^{3} \mathrm{H}$-labeled bacterial RNA from the wild-type strain 18 and from strain pro $A B 4^{7}$, deleted in the prophage attachment site and extending through the pro $A$ and $B$ cistrons, were hybridized to phage DNA obtained from lysates of induced 18(L11) and $18\left(L^{+}\right)$. As seen in Fig. 7, there was no significant hybridization of either RNA preparation to $L^{+}$phage DNA, whereas both RNA preparations bind to the defective $L 11$ DNA. In fact RNA from the pro $A B 47$ mutant, (deleted from the c-end through the pro $A$ and $B$ cistrons) binds a larger number of counts per microgram of defective phage DNA than does wild-type. Since the RNA was labcled with uridine $-{ }^{3} \mathrm{H}$ 


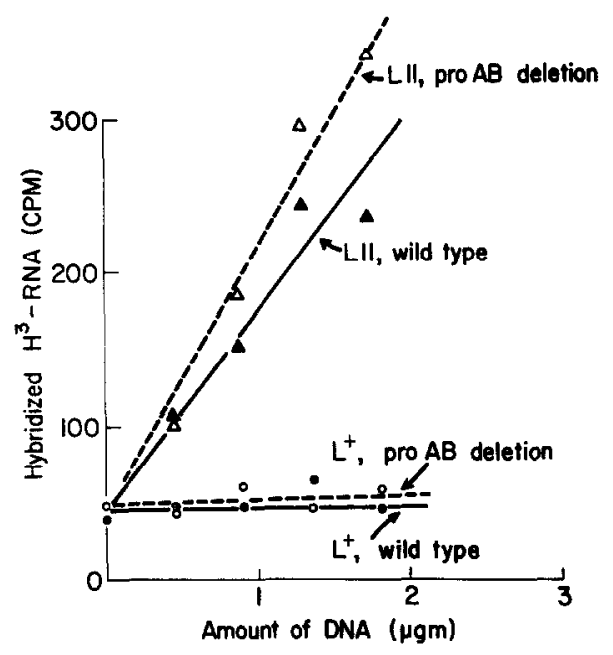

FIG. 7. Hybridization of ${ }^{3} \mathrm{H}-\mathrm{labeled}$ RNA from wild-type and pro $A B 47$ deletion mutant cells to $L^{+}$and $L 11$ defective DNA.

of the same specific activity in both cases, the specific activities of RNA should be identical. The deleted cells should produce no RNA not also present in wild-type cells, thus the amount of pro $A B 47$ RNA hybridized should not exceed that of wildtype. A possible explanation is that the cellular pool of uridine- ${ }^{3} \mathrm{H}$ is for some reason smaller in the mutant cells so that in reality the RNA is labeled at a higher specific activity.

Hybridization of bacterial RNA to the defective DNA, but not to normal phage DNA, confirms that bacterial DNA is present in the defective phage. In addition, the bacterial component of DNA apparently does not come in significant amount from bacterial chromosome adjacent to the $c$-end of the prophage. A quantitative estimate of the fraction of the total DNA which is bacterial is impossible because complementary RNA species may not be present for all the bacterial DNA, and the specific activity of the complementary RNA is not precisely known. DNA-DNA hybridization experiments were carried out to circumvent these problems and to confirm the results of the $\mathrm{CsCl}$ gradient studies which indicated that much of the DNA content of the defective particles is bacterial in origin.

\section{DNA-DNA Hybridization Experiments}

Uniformly labeled phage and bacterial DNA preparations were sheared to a molecular weight of approximately $6 \times 10^{6}$ by passage through a No. 25 gauge needle (Iyer and Szybalski, 1963). The sheared DNA's were then hybridized to a large excess of bacterial or phage DNA immobilized on membrane filters. As controls, bacterial DNA and $L^{+}$phage DNA obtained from lysates produced by infection and by UV induction were used. Bacterial DNA hybridized with an efficiency of $24 \%$ to bacterial DNA. Only $2.2 \%$ was bound to a filter containing phage DNA, and $0.2 \%$ was bound nonspecifically to a blank filter (Table 6). Normal phage DNA obtained by infection or by induction hybridized $17 \%$ and $23 \%$, respectively, to phage DNA filters and only $0.5 \%$ and $2 \%$ to bacterial DNA. The DNA from defective $L 3$ and $L 11$ phages, however, showed extensive homology to bacterial DNA, $28.6 \%$ and $13.2 \%$ being bound, respectively; lesser amounts, $14.5 \%$ and $10.4 \%$, were bound to phage DNA. These results leave little doubt that the defective particles contain the greater portion of bacterial IDNA. A rough estimate of the

TABLE 6

Hybridization of Defective Particle DNa to Bacterial and Phage DNa

\begin{tabular}{lccccc}
\hline \multirow{2}{*}{ Source of DNA } & Total $\mu \mathrm{g}$ & Total cpm & \multicolumn{2}{c}{ Percentage of counts hybridized to } \\
\cline { 4 - 6 } & & & Blank filter & Bacterial DNA & Phage DNA \\
\hline Bacterial & 0.1 & 2800 & 0.2 & 23.9 & 2.2 \\
$L^{+}$phage by infection & 0.15 & 7100 & 0.2 & 0.5 & 17.2 \\
$L^{+}$phage by induction & $\mathbf{0 . 0 5}$ & 850 & 1.2 & 2.1 & 22.8 \\
$L 3$ defective phage & $\mathbf{0 . 0 1}$ & 1550 & 0 & 28.6 & 14.5 \\
$L 11$ defective phage & $\mathbf{0 . 0 0 6}$ & 870 & 0 & 13.2 & 10.4 \\
\hline
\end{tabular}


TABLE 7

Frequency of Transduction of Various Bacterial Markers by Defective Li1 Particles ${ }^{a}$

\begin{tabular}{lccccccc}
\hline \multirow{2}{*}{ Phage } & \multicolumn{7}{c}{ Transductants per $10^{6}$ particles } \\
\cline { 2 - 7 } & leu 197 & his G203 & pro A15 & pro B25 & pro C90 & pur $E$ \\
\hline$L^{+}$(infection) & 0.60 & 1.8 & 0.53 & 0.37 & 0.35 & 0.19 \\
$L 11$ (infection) & 0.42 & 1.6 & 0.41 & 0.34 & 0.32 & 0.10 \\
$L^{+}$(induction) & 0.21 & 0.52 & 0.80 & 1.9 & 5.3 & 6.8 \\
L11 (induction) & 0.15 & 0.19 & 1.0 & 1.6 & 22.0 & 21.8 \\
\hline
\end{tabular}

${ }^{a} \mathrm{CsCl}$-purified phage suspensions prepared by infection or induction were assayed for transducing particles using various auxotrophic recipients lysogenic for P22 sie. Only complete transductants were scored. Absolute phage particle concentration was determined by optical density at $260 \mathrm{~m} \mu$. The phage produced by induction were saturated with phage tails prior to being used as described by Israel (1967) to assure normal adsorption.

bacterial DNA content of the defective phage DNA can be obtained by dividing the percent DNA hybridized to bacterial DNA by the total hybridized to both phage and bacterial DNA. For $L 3$ and $L 11$ DNA the respective values are $68 \%$ and $58 \%$.

\section{Frequency of Proline Transduction by Defec- tive Lysates}

The RNA-DNA hybridization results, using RNA, from the pro $A B 47$ bacterial mutant which is delcted extensively in the bacterial chromosome adjacent to the $c$ end of the prophage (Fig. 6), were suggestive that the defective particles derive little if any of their bacterial DNA content from the pro $A$ and $B$ region. RNA from this strain was not diminished in species homologous to the defective phage DNA. This somewhat surprising finding would imply that the bacterial content was from the pro $C$ side, adjacent to the $m$-end of the prophage. If so, the transduction frequency for pro $C$ might be increased in defective lysates. A CsCl-purified lysate prepared from $18(L 11)$ was tested for frequency of transduction of the proline markers. Genes leu, his, and pur $E$ at a distance from the prophage were used for comparison. As controls transductions were also performed using preparations of $\mathrm{L}^{+}$ phage obtained by induction and $L^{+}$and L11 phage obtained by infection.

Two findings are of interest. First, there is a significantly higher transduction rate for the proline and pur $E$ markers than for leu and his markers when lysates obtained by induction of prophage are used; lysates produced by infection show no large difference (Table 7). It thus seems likely that induced lysates contain special transducing particles for the proline regions which occur at frequencies significantly above the background of general transducing particles. Special transducing particles for proline have in fact been described for phage P22 (Smith-Keary, 1966). Secondly, the L11 defective particles produced by induction gave an even higher frequency of transduction for pro $C$ and pur $E$ than was observed with $L^{+}$phage obtained by induction. A decrease in leu and his transduction is also apparent as compared to that obtained from phage produced by infection. The representation of transducing particles among L11 defective particles is apparently polarized toward the pro $C$ side. The effect seems to be an exaggeration of that found for $L^{+}$phage obtained by induction.

This polarized representation of transducing particles extends at least as far as pur $E$ (see map position in Fig. 6). It is possible that a segment of the bacterial chromosome extending for several minute-units along the bacterial map is being selectively packaged into phage heads so that the whole segment represents a high transduction region. If this interpretation is correct it helps to establish an orientation for the proline region with pro $C$ nearest to pur $E$ (Fig. 6).

The higher content of pro $C$ and pur $E$ 
TABLE 8

Rescue of $t s^{+}$Phage Markers from Defective $L$ Particles ${ }^{a}$

\begin{tabular}{lccc}
\hline \multirow{2}{*}{ Marker } & \multicolumn{2}{c}{ Frequency of rescue } & \multicolumn{2}{c}{$\begin{array}{c}\text { Rescue } \\
\text { relative to } L^{+}\end{array}$} \\
\cline { 2 - 3 } & $\begin{array}{c}\text { CV-inacti- } \\
\text { vated } L^{+} \\
\text {phage }\end{array}$ & $\begin{array}{c}L 17 \text { defective } \\
\text { particles }\end{array}$ & $\begin{array}{c}\text { L17/UV- } \\
\text { inactivated } L^{+}\end{array}$ \\
\hline B9 & 3 & 224 & 75 \\
G5 & 44 & 454 & 10.3 \\
$B 11$ & 151 & 510 & 3.3 \\
$B 62$ & 545 & 1550 & 2.8 \\
$B 7$ & 281 & 0 & 0.0 \\
$B 12$ & 483 & 15 & 0.03 \\
\hline
\end{tabular}

a Marker rescue was performed as described under Materials and Methods. The data given for frequency of rescue are the actual number of plaques obtained.

transducing phage in the defective L11 preparation lends support to the idea that the bacterial DNA content of the defective phage is derived from the bacterial chromosome adjacent to the $m$-end of the prophage. If the origin of such particles is analogous to the origin of special transducing particles in other phage systems, e.g., $\lambda$ phage, then these particles might be expected to lack some phage DNA from the distal $c$-end.

\section{Rescue of Phage Markers from Defective Particles}

The content of the defective lysates for various phage genes was estimated by measuring the frequency of rescue of several ts markers. As a control, UV-inactivated wild-type phage was used to ascertain the frequency of rescue of the various markers when all are equally represented. The ratio of rescue frequency in defective lysates to that in the control lysate was used as a measure of the degree of representation of each marker in the defective phage. In Table 8 (last column) the ratio of rescue in $L 17$ phage to that in UV-inactivated $L^{+}$control phage varies from 75 for the $B 9$ mutant to essentially zero for the $B$ \% and $B 12$ mutants. A gradient of rescue exists which corresponds closely to the order of the mutants on the prophage map, i.e., $B 9, G 5, B 11, B 62,(B 7, B 12)$. It is clear that prophage markers at the $c$-end (distal to pro $C$ ) of the prophage are represented at very low frequency among the defective particles while those proximal to pro $C$ occur at higher frequency. To eliminate possible arguments that the gradient represents physiological effects of the ts mutants which alter rescuability, experiments were performed to measure rescue of the morphological markers $m_{3}, c_{2}$, and $h_{21}$. Again UV-inactivated $L^{+}$phage was used as a control. $L^{+}$phage was crossed with $m_{3} \quad c_{2} h_{21}$ phage. The total frequencies of $m_{3}{ }^{+}, c_{2}{ }^{+}$, and $h_{21}{ }^{+}$plaques among the recombinants were 88,73 , and 154 , respectively (Table 9). In contrast, when L11 defective phage was crossed with $m_{3} c_{2} h_{21}$ phage, 86 plaques were $\mathrm{m}_{3}{ }^{+}$, but only 5 plaques were $c_{2}{ }^{+}$and 6 were $h_{31}{ }^{+}$(Table 9 ). The data are most consistent with the notion that a spectrum of defective particles exists in a lysate ranging from normal phage on one extreme to phage carrying only bacterial DNA derived from the pro $C-$ pur $E$ region on the other extreme. In between exists a continuum of those particles containing genomes consisting partly of phage DNA and partly bacterial DNA (Fig. 8).

TABLE 9

Rescue of Morphological Markers from UV-Inactivated $L^{+}$Phage and From $L 11$ Defective Particles

\begin{tabular}{|c|c|c|c|c|c|c|c|c|c|c|c|}
\hline \multirow{2}{*}{ Cross } & \multicolumn{8}{|c|}{ Frequency of progeny types } & \multicolumn{3}{|c|}{ Marker rescue totals } \\
\hline & $m \in h$ & +++ & $+c h$ & $m++$ & $m+h$ & $+c+$ & $m c+$ & $++h$ & $m^{+}$ & $c^{\prime \prime}$ & $h^{-}$ \\
\hline $\mathrm{UV}$-inactivated $L^{+} \times m c h$ & 9,000 & 29 & 43 & 19 & 23 & 14 & 92 & 2 & 88 & 73 & 154 \\
\hline$L 11 \times m c h$ & 18,000 & 4 & 81 & 1 & 0 & 1 & 0 & 0 & 86 & 5 & 6 \\
\hline
\end{tabular}

a Complete data are given for each cross. Marker rescue totals represent the sum of each single marker class, c.g., $m_{3}^{+}=(+++)+(+c h)+(+c+)+(++h)$. 
LINKAGE MAP OF PROPHAGE P 22

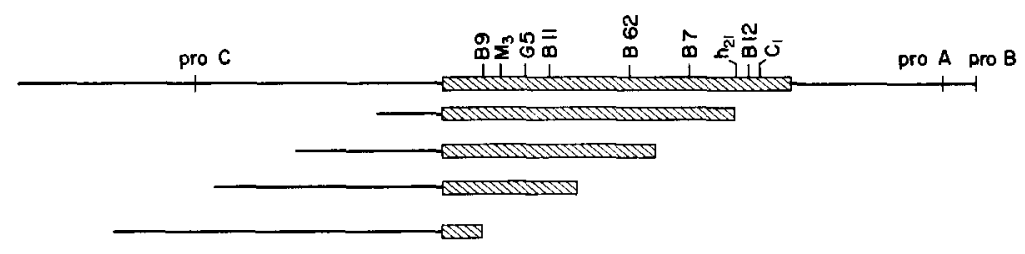

FIG. 8. An illustration of the proposed spectrum of genomes contained in a lysate of defective par. ticles. The particles would contain no bacterial chromosome from the pro $A$ region, but would carry variable amounts of phage DNA and bacterial DNA frum the pro $C$ region.

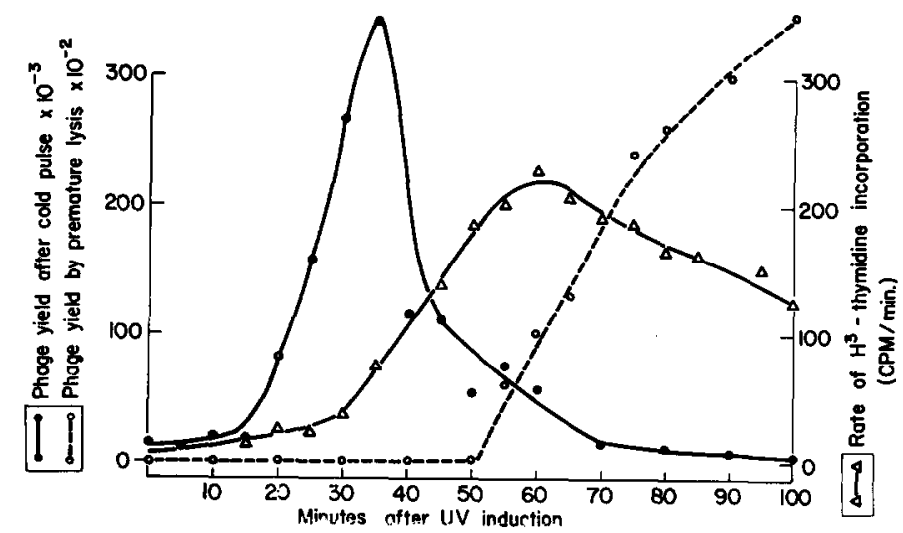

FIG. 9. Kinetics of action of the $L$ gene product after UV induction of $18(L 30)$. The final infectious phage yield in each aliquot is plotted against the time at which the 10 -minute cold pulse $\left(25^{\circ}\right)$ was begun. Intracellular phage development was followed by measuring PFU in small chloroform-treated aliquots at each time. Half-milliliter aliquots were also pulsed for 1 minute with thymidine-3${ }^{3} \mathrm{H}$ (specific activity $=$ $640 \mathrm{mC} / \mathrm{mmole}, 10 \mu \mathrm{C} / \mathrm{ml}$ ) at each time, and trichloroacetic acid-precipitable counts were measured.

Kinetics of Action of $L^{+}$Function in the Formation of Phage

Lysogen $18($ L30) is markedly temperature-sensitive to formation of infectious phage following UV induction. It yields approximately 0.007 infectious phage per UV-irradiated cell at $37^{\circ}$ and 25-50 phage per cell at $25^{\circ}$. By appropriate temperature shifts following induction it is thus possible to determine when the function is most necessary for production of infectious versus defective phage. The lysogen was grown in log phase, UV-induced at time zero, and then incubated at $37^{\circ}$, the restriclive temperature. At 5-minute intervals aliquots were exposed to $25^{\circ}$ for 10 minutes (cold-pulsed) and then returned to $37^{\circ}$ to complete lysis. The effect of the cold-pulse was to permit expression of $L^{+}$function during that inter- val. If $L^{+}$function were necessary during the given interval then the final infectious yield of that aliquot should be increased. In Fig. 9 it can be seen that final yields were augmented by a cold-pulse occurring 20-50 minutes after UV treatment, the peak response occurring at 35 minutes. Other events in the phage growth cycle, onset of DNA synthesis and development of intracellular phage, were measured simultaneously and are shown on the same time scale. DNA synthesis begins at 35 minutes when the $L^{+}$ function is most active. Intracellular phage begins to accumulate at 50 minutes. Thus $L^{+}$function is required as one of the earliest events, simultaneous with, or slightly preceding the initiation of phage DNA synthesis. 


\section{DISCUSSION}

The $L$ mutants are capable of carrying out coordinated $c_{1}, c_{2}$, and $c_{3}$ function to produce the reductive response leading to cell survival. However, they are deficient in ability to integrate as prophage to complete the lysogenic response. In mixed infection with $L^{+}$and $L$ phage the $L^{+}$gene product is capable of acting trans to permit integration of the $L$ phage genome. Once established the $L$ prophage remains stably integrated in the absence of $L^{+}$function (Smith and Levine, 1967). Such $L$ lysogens have the interesting property that inducing levels of UV irradiation produce, in most instances, very low yields of infectious phage. The main features of this effect are that (a) the induction per se appears completely normal in that the cells are killed by the inducing treatment and lyse with the usual kinetics seen for wild-type lysogens; (b) phage particles are produced in near normal yield; (c) the vast majority of the progeny particles are defective; (d) defectiveness resides in the DNA of the particle rather than the capsid; the DNA content is normal in amount but consists mainly of bacterial DNA, which may come largely from the bacterial chromosome neighboring on the $m$-end of the prophage. The defective lysates transduce pro $C^{\prime}$ and pur $E^{\prime}$ from this region at higher frequency than markers bordering on the $c$-end of the prophage; (e) the representation of phage markers among the defective particles is strongly polar. Genes near the $c$-end are present at low frequency while those near the $m$-end are represented at much higher frequency.

It is clear that $L^{+}$function is required not only for efficient integration, but for normal recovery of the prophage genome after induction. An abnormal mechanism operates in the $L$ lysogen after an inducing treatment which results in faulty prophage information retrieval. However, the mechanism of retrieval is not random. The DNA selected for replication and encapsulation into phage heads comes from the prophage and from that part of the chromosome bordering on the $m$-end of the prophage. Recovery of bacterial genome from the $c$-end region (pro $A$ and pro $B$ ), or from elsowhere on the chromosome, is not increased.
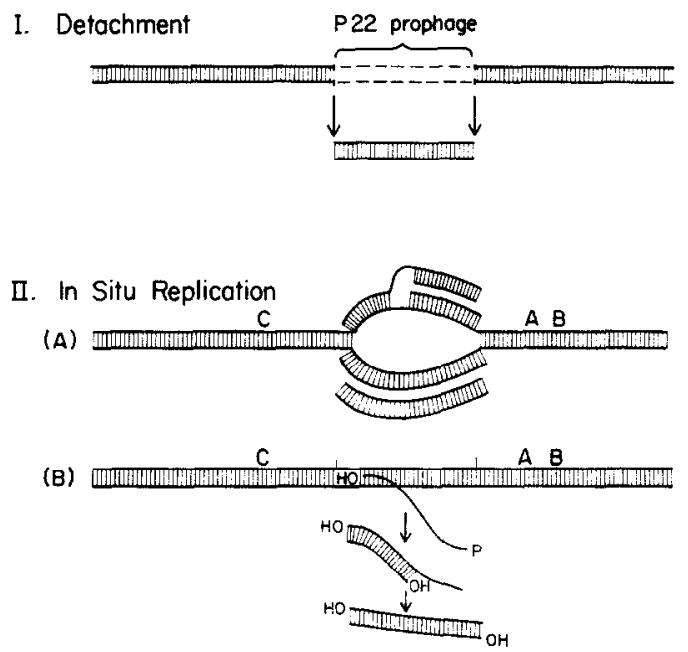

FIG. 10. Schematic representation of various models for retrieval of the prophage genome following induction. Model I illustrates a simple pliysical detachment mechanism. Model II A shows how the genome can be extracted by replication on the in situ prophage template. After 2 rounds of replication two of the genomes would be free and contain none of the original prophage DNA. Model II B although formally possible, departs more radically from known semiconservative mechanisms for DNA replication. It is postulated that a single strand IDNA could be "transcribed" in a way analogous to messenger RNA transcription from the DNA template. The free single-strand DNA could then serve as a template for formation of the complementary strand.

Before attempting to explain the abnormal mechanism operating in $L$ lysogen induction, it is worthwhile to consider various hypotheses for the normal induction process. What is the mechanism by which prophage is precisely identified, replicated, and packaged into mature infectious progeny phage? Two inclusive possibilities exist. (I) The prophage DNA is recognized and precisely removed from the bacterial chromosome by "detachment." (II) The prophage is not physically detached. Copies are replicated from the in situ template (Fig. 10). Both alternatives inherently demand recognition of the prophage ends. As yet no data are available to exclude either mechanism although in the phage $\lambda-E$. coli system there is evidence that detachment may occur (Ptashne, 1965). The high incidence of curing following induction of mutant $\lambda_{T 11^{-}}$ lysogens also indicates a detachment mecha- 
nism (Eisen et al., 1966). Similar evidence is presently lacking for phage P22 lysogens.

For the discussion of induction of $L$ lysogens, a detachment mechanism will be considered first. For two reasons, it seems unlikely that phage-size pieces are being detached. First, detachment is an all-ornone process. If the exact genome is detached in a particular induced cell, then that cell should yield a sizable burst of infectious phage, while a detachment not containing the complete prophage would lead to no infectious phage. Single-cell burst experiments show, however, that partial yields are the rule, in direct contradiction to this mechanism. Secondly, it is difficult to conceive of a mechanism which involves random recognition of ends to be excised, and yet measures an exact phage length to be detached, and also limits its "random" recognition to the pro C-pur $E$ region of the chromosome. It is more likely that a larger than phage-size piece of DNA is selected for detachment from the chromosome. To be consistent with the single-burst and transduction data the piece should include the prophage and extend beyond the $m$-end into the neighboring bacterial chromosome (pro $C$ region). Given that this larger than phage-size piece of DNA is selected for replication, it becomes important to specify how phage-size pieces are cut from it to become encapsulated into phage heads. A random process, although inefficient, would produce the type of DNA spectrum which has been described (Fig. 8). Suppose for simplicity of argument that the detached DNA is twice as long as the prophage genome, and that the prophage consitutes the right half of the detached segment. All phage-size pieces would contain some phage markers except that obtained by selecting the precise left half. It is easy to visualize that essentially all the phage-size pieces selected for encapsulation would contain markers from the $m$-end but only rarely would markers at the extreme $c$-end be encapsulated. Such a mechanism is consistent qualitatively with the data.

Nondetachment models would be restricted, by arguments similar to those stated above, to replication from a longer than phage-size template extending from the $c$-end of the prophage to beyond the $m$-end. Such in situ replication has the added feature that the undefined $m$-end might be variable in the same cell, so that a number of different lengths might be replicated free. A similar phage-size encapsulation mechanism could be invoked to produce polarity of phage gene representation.

It is possible that the $L^{+}$product is a specific "recombination" enzyme for the bacterial and phage attachment regions and that integration occurs as a localized and specific recombination process (Campbell, 1962). The same enzyme could be easily visualized as necessary for producing detachment of the prophage. The $L$ mutant, lacking this function, would depend on other less specific recombination mechanisms present in the cell, or specified by the phage, for detachment. Or, in the absence of such nonspecific mechanisms for detachment, the in situ prophage might act as template, with DNA polymerase recognition of the $c$-end as an initiation point but with no recognition at the $m$-end as a termination point.

On the basis of results reported here, it is not possible to argue strongly for or against a replication mechanism for $L$ prophage induction. However, such a mechanism is appealing because it suggests a possible analogy with $\mathrm{F}$-factors. It seems likely that F-factors lack a specific integration mechanism because they attach at various points on the chromosome at very low efficiency. They also apparently lack a specific detachment mechanism. When a rare detachment event occurs the episome frequently becomes associated with a segment of adjacent bacterial chromosome. Conjugation between $\mathrm{Hfr}$ and $\mathrm{F}^{-}$cells "induces" an episomal mechanism and replication proceeds unidirectionally around the chromosome from a starting point in the episome (Adelberg and Pittard, 1965).

Defective lysates transduce the bacterial gene pro $C$ and also apparently pur $E$ at frequencies considerably higher than more distant markers or genes bordering on the opposite side of the prophage. Phage P22 is well known as a general transducing phage (Zinder and Lederberg, 1952) but has only recently been shown to produce 
special transducing particles for the proline loci which behave similarly to the $\lambda d g$ particles of phage $\lambda$ (Smith-Keary, 1966). Phage P22 lysates produced by infection are presumed to contain transducing particles arising by some common mechanism which produces general transducing particles for any gene on the bacterial chromosome. Such lysates, although producing considerable variability in the number of complete transductants for different genes, do not reveal any disproportionately increased transduction frequency for the proline markers situated near the prophage. However, lysates obtained by induction of prophage, show a significant and consistent increase in proline transduction frequency, compatible with formation of special transducing particles in addition to general transducing particles (refer to Table 7). Lysates obtained by induction of $L$-mutant lysogens show an increased frequency of pro $C$ transduction compared to other genes. It seems possible that some contribution to special transducing particles, at least of the pro $C$ type, may normally stem from rare mutations, $L^{+} \rightarrow L$, in the population. By similar reasoning one could also speculate on the presence of another gene mutation, $X^{+} \rightarrow X$, which would give rise to pro $A$ and $B$ special transducing phage. Such a proposal would be in opposition to a theory of random "accidental" errors in prophage detachment as the sole mechanism of special transducing phage formation.

The class II mutants show nearly normal yields of infectious phage after induction at both $25^{\circ}$ and $37^{\circ}$, and thus seem to be lacking the general property of the $L \mathrm{mu}$ tants for producing predominantely defective particles. It has been shown that the $L$ mutants tend to form frequent double lysogens when complemented with $L^{+}$phage. The possibility exists that these class II lysogens are $L, L$ double lysogens or conceivably even higher orders. Induction of a double $L, L$ lysogen could lead to "looping out" of a complete phage genome because of extensive homology, leaving behind a single prophage. Such a mechanism has been shown to occur following induction of $\lambda b 2$ double lysogens (Fischer-Fantuzzi, 1967). The looping out would not occur generally at the attachment site regions and could use phage-specific recombination mechanisms derepressed by the induction treatment. Removal of the remaining single prophage would have to proceed by the faulty $L$ mechanisms. Such lysates could thus contain a high yield of normal phage and also defective particles, accounting for the high pro $C$ transduction rate seen for lysates from these lysogens.

Class IV mutants have a high index of temperature sensitivity on induction but are nontemperature sensitive with respect to integration. The apparent dissociation in these mutants of the integration and detachment functions suggests the existence of two functional regions of the $L$ gene. The frequency of ts $L$ mutants is in itself surprising. There is evidence that even the wild-type $L$ function is temperature-sensitive (Smith and Ievine, 1967). There may be an inherent temperature sensitivity to the integration and detachment processes.

\section{ACKNOWLEDGMENTS}

I wish to thank Lee Gough for technical assist ance in the performance of many of the experiments and David Botstein, Micheal (xough, Vance Israel, Jennifer Patai Wing, and Nagaraja Rao for providing many stimulating discussions and suggestions.

I especially wish to thank Myron Levine in whose laboratory all of my work for the past five years has been performed and who has served as a teacher, friend, and collaborator in research.

\section{REFFRENCES}

Abelabrg, E. A., and Pittakd, J. (1965). Chromosome transfer in bacterial conjugation. Bacteriol. Rev. 29, 161-172.

Burgi, E., and Hershex, A. 1). (1963). Sedimentation rate as a measure of molecular weight of 1)NA. Biophys. J. 3, 309-321

Campbell, A. (1962). Episomes. Adran. Genet. 11, 101-145.

1)ENHARDT, 1). 'T. (1966). A membrane-filter technique for the detection of complementary I.SNA. Biochem. Biophys. Res. Commun. 23, 641-64i.

Eisen, H. A., Fuerst, C. R., Nimixoviteli, J., Thomas, R., Lambert, I., D) sink, I. P., and $\mathrm{JACOH}_{\mathrm{ACO}}$ F. (1966). Geneties and Physiology of defective lysogeny in $\mathrm{K} 12(\lambda)$ : Studies of early mutants. Virology 30, 224-241.

Fischer-Fantuzzi, L. (1967). Integration of $\lambda$ and $\lambda b 2$ genome in nonimmune host bacteria 
carrying a $\lambda$ eryptic prophage. Virology $32,18-$ 32.

Gillespie, D., and Spiegelman, S. (1965). A quantitative assay for DNA-RNA hybrids with DNA immobilized on a membrane. J. Mol. Biol. 12, 820-842.

Gough, M., and Levine, M. (1968). Circularity of the phage $\mathrm{P} 22$ linkage map. Genetics, in press.

Green, M. H. (1966). Inactivation of the prophage lambda repressor without induction. J. Mol. Biol. 16, 134-148.

IFFT, J. B., Voet, D. H., and Vinograd, J. (1961). The determination of density distributions and density gradients in binary solutions at equilibrium in the ultracentrifuge. J. Phys. Chem. 65, 1138-1145.

IsRAEL, V. (1967). The production of inactive phage P22 particles following induction. $V i$ rology 33, 317-322.

Israel, V., Anderson, T. F., and Levine, M. (1967). In vitro morphogenesis of phage P22 from heads and base-plate parts. Proc. Natl. Acad. Sci. U.S. 57, 284-291.

IYer, V. N., and Szybalski, W. (1963). A molecular mechanism of mitomycin action: Linking of complementary DNA strands. Proc. Nall. Acad. Sci. U.S. 50, 355-362.

IEvine, M. (1957). Mutations in the temperate phage P22 and lysogeny in Salmonella. Virology 3, 22-41.

Levine, M., and Smith, H. O. (1964). Sequential gene action in the establishment of lysogeny. Science 146, 1581-1582.

Miyake, T., and Demerec, M. (1960). Proline mutants of Salmonella typhimurium. Genetics 45, 755-762.
Ptashne, M. (1965). The detachment and maturation of conserved lambda prophage DNA. $J$. Mol. Biol. 11, 90-96.

Sanderson, K. E., and Demerec, M. (1965). The linkage map of Salmonella typhimurium. Genetics 51, 897-913.

Smith, H. O., and Levine, M. (1964). Two sequential repressions of DNA synthesis in the establishment of lysogeny by phage P22 and its mutants. Proc. Nall. Acad. Sci. U.S. 52, 356-363.

Smith, H. O., and Levine, M. (1965). Gene order in prophage P22. Virology 27, 229-231.

Smith, H. O., and Levine, M. (1966). A late function in the establishment of lysogeny in the phage P22-Salmonella typhimurium system. Abstr. 9th Intern. Congr. Microbiol., Moscow, 1966 , p. 481.

Smith, H. O., and Levine, M. (1967). A phage P22 gene controlling integration of prophage. $\mathrm{V} i$ rology $31,207-216$.

Smith-Keary, P. F. (1966). Restricted tranduction by bacteriophage P22 in Salmonella typhimurium. Genet. Res. 8, 73-82.

Studier, F. W. (1965). Sedimentation studies of the size and shape of DNA.J. Mol. Biol. 11, 373390.

Weigle, J., Meselison, M., and Paigen, K. (1959). Density alterations associated with transducing ability in bacteriophage lambda. J. Mol. Biol. 1, 379-386.

ZiNDer, N. D. (1958). Lysogenization and superinfection immunity in Salmonella. Virology $\mathbf{5}$, 291-326.

Zinder, N. D., and Lederberg, J. (1952). Genetic exchange in Salmonella. J. Bacteriol. 64, 679-699. 